\title{
Roadside Tree Management in Urban Area for Public Safety and Properties
}

\author{
Ramly Hasan, Noriah Othman, Faridah Ismail \\ Faculty of Architecture, Planning and Surveying, \\ Universiti Teknologi MARA,40450 Shah Alam, Selangor, Malaysia \\ ramlyhasan80@yahoo.com
}

\begin{abstract}
Roadside planting is a row of trees along the road which provides shades for people in urban areas. Proper management practices among the local authorities will improve the quality of life and human well-being. Unhealthy trees may cause problems to the road users that result from the lack of monitoring by local governing bodies. 200 respondents from the public from Selayang Municipal Council and Shah Alam City Council have participated in this study. The data analysis showed that fallen trees were the main reason for the public to lodge complaints, followed by brittle branches, thick branches and leaning tree trunk.
\end{abstract}

Keywords: Roadside tree; management; local authority; fallen trees

eISSN 2398-4279 @ 2018. The Authors. Published for AMER ABRA cE-Bs by e-International Publishing House, Ltd., UK. This is an open access article under the CC BY-NC-ND license (http://creativecommons.org/licenses/bync-nd/4.0). Peer-review under responsibility of AMER (Association of Malaysian Environment-Behaviour Researchers), ABRA (Association of Behavioural Researchers on Asians) and cE-Bs (Centre for EnvironmentBehaviour Studies), Faculty of Architecture, Planning \& Surveying, Universiti Teknologi MARA, Malaysia.

https://doi.org/10.21834/ajqol.v3i11.132 


\subsection{Introduction}

Roadside tree management is a reduction of hazards through inspection and mitigation, maintaining the level of hazard with the need to keep large, beautiful trees on the site (James, 2010). Furthermore, this form of management is to enhance public safety makes the city more livable and improves the environment. Street planting is an important part of making our city cleaner and greener (Joan et al., 2012). Street planting with healthy condition properly care in urban areas have a direct impact on our community through the benefits they provide such as cooling the streets and the city, prevent soil erosion, block things and provide a canopy and habitat for wildlife.

Roadside trees are a bone for urbanites area to live and breathe. They are an essential component of urban areas and make the city more livable, improve the environment, enhance public health and one of the most beneficial and costeffective ways to support and advance our infrastructure. Overall, they offer benefits to the city, though the public may not understand these benefits or the street planting process (Ruth et. all, 2010). Therefore, the roadside trees are often graded according to the degree of hazards they pose on targets that could include humans and properties. Good roadside tree management is an image to scale the capability of local authority to manage their landscape to become beautiful and safe for people in their administrative areas (Bureau of Construction, Tokyo Metropolitan Government., 2014). The roadside tree management required incorporation of standards, staffing organization, planning and technique to groom the trees synchronize with public and worker safety. In additions, the management will influence the tree growth and form. Proper roadside tree management can reduce the liability cost for the local authorities and tree risk problems toward the public. The quality of service by the local authorities will be determined by the effectiveness and skill from local authorities to handle the public complaint.

The aim of this study is to investigate the user's preferences on roadside tree management at selected local authorities in Malaysia. Two objectives have been formulated as follow:

(i) To determine problems related to roadside trees at two local authorities.

(ii) To recommend ways to improve tree management from the user's perspectives.

Local authorities have their units or divisions or departments to carry out the role and functions of planning, implementation and development, maintenance and regulatory control of landscape in urban areas (Hisyam et. al, 2014). Some local authorities have entire landscape organizations while other local authorities put Landscape Unit in the Department of Urban Planning, Department of Environmental and some small local authority do not have clear landscape organization. According to Nor Azah (2015), tree management in local authority facing problems in term of lack of financial allocations, lack of professionals and skilled workforce to manage and maintain the management of hazardous trees. In the organization of tree management, lack of opportunities and training facilities among employees cause various issues and problems concerning hazardous trees cannot be managed efficiently and orderly (Chiu \& Chau, 2010). These issues affect the level and quality of tree management - rendering them unsatisfactory. Among the deficiencies in tree management, is a lack of knowledge, skills, exposure and training in particular in the field of tree management and maintenance (Hong Kong Conservancy Association, 2009). 
Furthermore, the duties and responsibilities related tree management was carried out by personnel who do not have the knowledge and expertise.

\subsection{Literature Review}

\subsection{Management of roadside trees at Malaysian local authorities}

According to National Landscape Department (2011), roadside trees can be categorized into two approaches which are tree inventory from local authorities or related agencies and complaints from the public. Local governing bodies or related parties implement tree inventories to get the population of trees in their administrative areas. The tree information covers the characteristics, physical conditions, and locations through geographic information system (GIS). The information will then be stored in the system database.

\subsection{Process of Public Complaint on Roadside Trees}

Public engagement to maintain the sustainability of roadside tree in urban areas is crucial. Malaysia local authorities nowadays establish the complaint network which can be accessed by the public. In the state of Selangor famous with Sistem Talian Aduan Rakyat Selangor (STARS), the public can directly report and complain to the

Selangor Corporate Secretary about the hazardous roadside trees to improve the quality of management services (Subang Jaya Municipal Council, 2015). STARS receive various types of feedback from the public in the form of complaints, suggestions, compliments, questions, and criticisms. Also, every local authority provides a complaint system for public to report every case involving the roadside trees. This effort can improve the quality of management and will improve the quality of life and human well-being. Local authorities need to take action to verify the complaint and records in a database. National Landscape Department (2011) produces a flowchart as guidance for local governments to manage the trees (Figure 1).

Fligure 1: Flow chart of public complaints

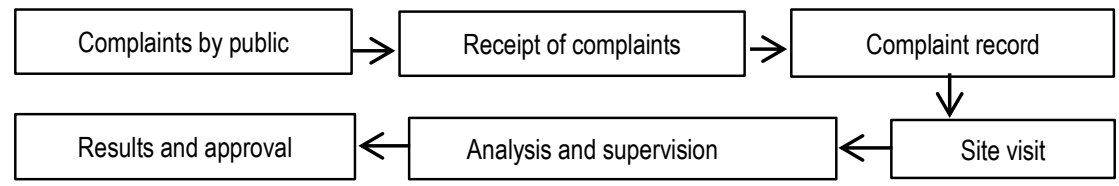

2.3 Numbers of complaint on roadside trees issues at local authorities

The increasing of number complaints by the public causes the local authorities need to spend more than ten thousand Ringgit Malaysia to pay the compensation (Yaman et al., 2011). According to landscape architect Ramzi (2016) at Subang Jaya Municipal Council and landscape architect at Selayang Municipal Council received more than thousands of complaint related to the roadside trees. At Subang Jaya Municipal Council, the total number of complaints been absorbed by Iresponz where it is the complaints online system while at Selayang Municipal Council, the total of complaints has been absorbed by MPS Aduan 
System, as shown in Figure 2. The complaint is more on the three top issues from the roadside trees namely leaning trees, falling trees and high density of canopy that disturb the utilities. According to the Department of Landscape and Recreation at City Hall Kuala Lumpur (2015), some existing roadside tree species are not suitable and located on steep slopes with angels above $45^{\circ}$. This includes trees planted in private areas and abundant government land, trees in the path of storms and natural disasters, trees within the alignment of high voltage overhead utility lines (International Society of Arboriculture, 2005) and trees within the proximity of monorail, and commuter train reserves. The physical nature of roadside tree species growth will be stunted i.e. trees with dieback symptoms, pests, and disease, exposed cavities on the main stem, trees with existing root system destroyed as a result of a road, drains, and other underground services. Trees with big roots will damage drain concrete walls, walkways, fire hydrants and underground sanitary pipes. In term of policies, there are no integrated policies and guidelines towards trees management set by the federal government until the local authorities as on-site implemented agencies. There is no standardization among 149 of local authorities in Malaysia. Some local authorities move forward to produce their guidelines to overcome the trees falling problems in their administration areas.

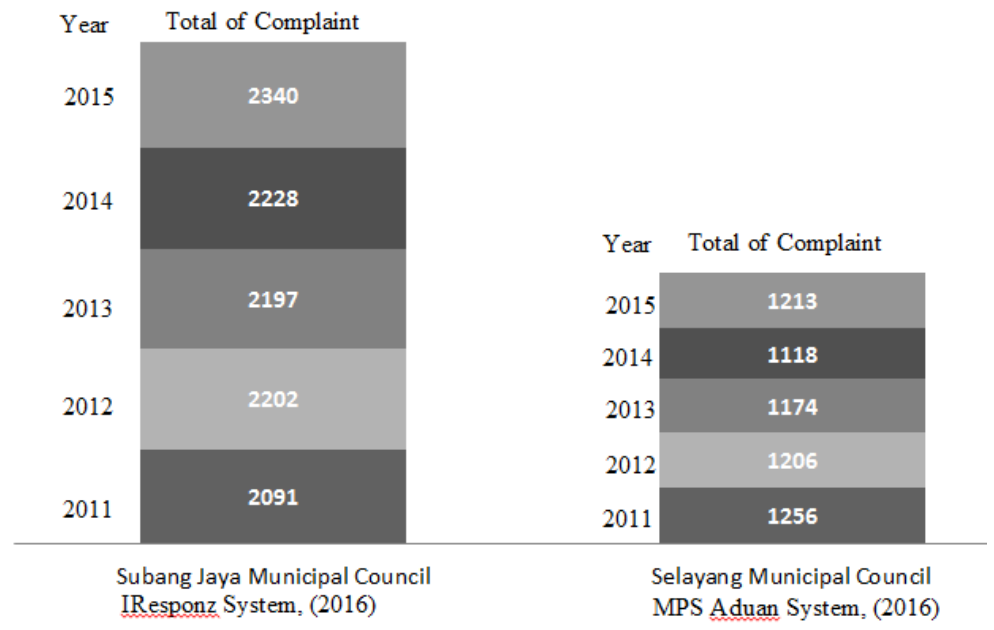

\subsection{Public safety on roadside trees}

The public's safety in highway and street in relation to roadside trees is a major concern of local authorities and agencies. In fact, roadway safety is impossible without an excellent management and maintenance program to manage roadside trees. The landscape department, arborist and expertise person at local authority is responsible for reviewing their roadside tree conditions, identifying hazards and making conditions safer. Roadside trees are a potential hazard. Trees close to the road can present a fixed object hazard. Grass, weeds, bushes, tree limbs and obstructing trees will obscure or limit a driver's view of traffic control devices, other vehicles, wildlife, and pedestrians. Local authorities need to control the 
tree planted at roadsides to ensure the comfort of pedestrian users and safety of motorists along the particular roads (Mohd Akmal \& Noriah, 2011) and to reduce crashes injuries and crime on urban roadways (Ronald \& huge, 2008; Naderi, 2003; Donovan, 2010). Moreover, public safety is a primary purpose for which the arborists perform his or her duties, including through the removal of trees in the right of way that constitutes a public hazard (John, 2012). Hence, public safety plays a significant role in every local authority. Avoiding fallen trees at the roadside becomes a priority for local authorities especially during raining season. This is because local authorities will be directly blamed for those incidents even those trees belong to other parties. This situation gives bad perception on how local authorities manage the roadside trees for public safety.

\subsection{Methodology}

\subsection{Selection of case study}

The study will select two local authorities which are Selayang Municipal Council and Subang Jaya Municipal Council. Previously, Selayang Municipal Council, also known as Gombak District Council. Established under the Local Government Act 1976, ACT 171. Selayang Municipal Council is divided into three main areas, namely Rawang district, Batu district and part of Setapak district. The total area cover of Selayang Municipal Council is 54560 hectares. Subang Jaya Municipal Council is divided into four zones where Subang Jaya, Kinrara, Puchong and Seri Serdang is. Subang Jaya zone was chosen because of the high density and administration center for Subang Jaya Municipal Council. The total area of Subang Jaya Municipal Council is $161.8 \mathrm{~km} 2$. The selection of study area is based on the highest online systems of public complains related to roadside trees in Klang Valley. Among the online methods that can be used by publics to complaint at Selayang Municipal Council known as MPSJ Online Public Complaints System (IResponz) while at Subang Jaya Municipal Council, known as MPS Aduan System. This system will help the local authorities to improve the management of roadside trees.

\subsection{Questionnaires survey}

The development of questionnaires was based on preliminary studies conducted by the researcher. The questionnaires for assessing public preferences for management of roadside trees were divided into three sections. Section one consists of the demographic information of the respondents while Section two covers the importance of roadside tree management by selected local authorities and Section three, which contains open-ended questions, highlights public opinions and awareness toward roadside tree management. The open-ended verbal response is useful in acquiring qualitative data. Selection of the respondent based on random sampling and living in Klang Valley district. Respondents for this study are the public at Selayang Municipal Council administration and Subang Jaya Municipal Council administration. Hundred respondents from each municipal council participated in answering the questionnaires. The totals of respondents are 200 people. The 
respondents based on three main ethnic groups in Klang Valley namely Malays, Chinese and Indian. The sample size is based on an ethnic ratio (70 percent Malay and 30 percent consist Chinese and Indian), and only willing members of the public were interviewed.

\subsection{Data analysis}

The methods applied in this research are qualitative and quantitative approaches. For the quantitative data, the researcher uses Statistical Packaging for Social Science (SPSS) version 22 to analyze data. Statistical Packaging for Social Science is data management and statistical software package that is capable of processing any data and use to generate bar charts, descriptive statistics, tabulated reports even sophisticated statistical analysis. The first step in the process was exploring the characteristics of the data. For more objective quantitative analysis, the researcher often employed a variety of statistical techniques. Qualitative data were collected from the observation by the researchers.

\subsection{Findings and Discussions}

\subsection{Frequency of Respondents}

Table 2 shows the total number of respondents from different ethnics in this study. The majority of the respondents is from the Malay ethnic $47 \%$, followed by Chinese $38 \%$ and Indian 15\%. The results show the majority of public interested to participate in this survey because they need the positive feedback and improving the management of roadside trees.

Table 2. Frequency of respondents based on ethnic groups

\begin{tabular}{ccccc}
\hline Race & $\begin{array}{c}\text { Selayang Municipal } \\
\text { Council } \\
(\mathrm{n})\end{array}$ & $\begin{array}{c}\text { Subang Jaya } \\
\text { Municipal } \\
\text { Council } \\
(\mathrm{n})\end{array}$ & $\begin{array}{c}\text { Total } \\
(\mathrm{n})\end{array}$ & $\begin{array}{c}\text { Percent } \\
(\%)\end{array}$ \\
\hline Malay & 43 & 51 & 94 & $47 \%$ \\
Chinese & 40 & 36 & 76 & $38 \%$ \\
Indian & 17 & 13 & 30 & $15 \%$ \\
Total & 100 & 100 & 200 & $100 \%$ \\
\hline
\end{tabular}

(Source: Author)

\subsection{Reason of roadside trees complaint to the local authorities}

Figure 3 shows the types of roadside trees problems at Subang Jaya Municipal Council and Selayang Municipal Council administrations. 146 of the public strongly agreed that fallen trees are the main reason for problems in roadside trees followed by 137 of the public strongly agreed that old and dead trees are the cause of roadside trees problems. 134 of the public agreed that planted trees too near to residential areas while 117 of the publics agreed that trees cause the district visibility. However, 99 of the publics agreed that trees debris obstructed the drainage system at roadside areas. 89 of the publics agreed that brittle branches are the reason of public complaint to the local authorities. Only 20 from the public moderate agree on fallen trees, old and dead tree and trees planted near to residential areas. 
Regarding the fallen trees at roadside nowadays, many cases occurred and reported by newspapers. This accident caused loss of life and properties damages. The public will feel phobias and unsafe during at roadway especially when rain and storms. The proactive management by the local authorities will reduce the fallen trees and can increase the public safety thus improve the quality of human life and human well-being.

Figure 3. Types of roadside trees problems on public complaint

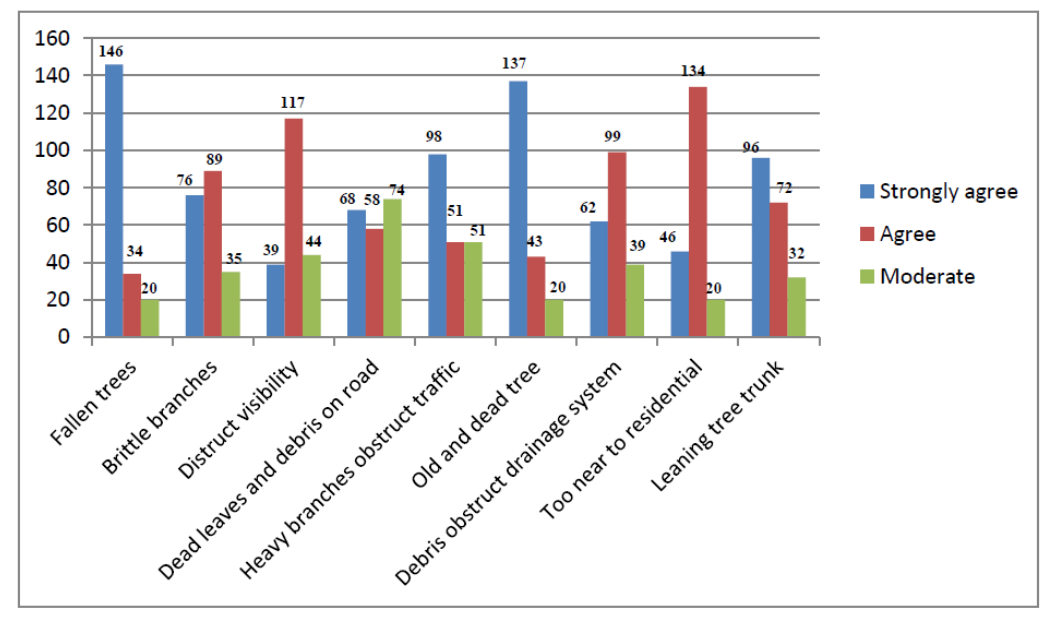

(Source: Author)

\subsection{Ways to improve the roadside tree management by local authorities}

Figure 4 shows the ways of improving the roadside tree management. Most public thought that consult in-house and hired a contractor on roadside tree maintenance procedure $(h)$ is the most prioritize things to by local authorities with $45 \%$. Next, $44 \%$ of the public from three different areas agreed that local authorities should invest more in maintaining roadside tree (g). The respondents also thought that local governing bodies should inspect every works done by the contractor (f) with $43 \%$ of the public think that is the most prioritize to be concerned. The public also felt that local authorities should establish penalty on improper maintenance works (e) done by the contractor with $41 \% .39 \%$ of the public believe that the most prioritize in improving the roadside tree management $(b)$ is through regular supervision works on roadside tree maintenance, and also, local authorities should hire an expert in doing the maintenance (c). While $37 \%$ public responds on local governing bodies should ally with the traffic expert to reduce traffic congestion (d) as the most priority things to concern. Lastly, only $36 \%$ of the public think about developing acts and guidelines (a) as the most priority to take care of to improve the roadside tree management. The effectiveness of roadside tree management among local authorities needs to improve to enhance the quality of human life. For example, the Landscape Department should develop Standard Operating Procedure (SOP) for monitoring roadside trees (Nuranisyah, 2015). Good ways and proactive 
management will reduce the number of public complaint regarding roadside trees. Furthermore, local authorities need to improve the quality of their services on roadside trees such as gives properly maintenance.

\subsection{Recommendations on Management of Roadside Trees}

This part of the survey was made to obtain the general public's recommendation and needs, roadside trees maintenance and planting space requirement.

Table 3. Public recommend for trees maintenance by local authority.

\begin{tabular}{lll}
\hline Frequencies & Respondents (n) & Percentages (\%) \\
\hline Every year & 12 & $6 \%$ \\
Every six months & 96 & $48 \%$ \\
Every two months & 58 & $29 \%$ \\
Based on public complaints & 34 & $17 \%$ \\
Total & 200 & $100 \%$ \\
\hline
\end{tabular}

(Source: Author)

Table 3 shows the public wanted roadside trees to be maintained every six months with $48 \%$, followed by 58 of the public wanted the trees to be maintained every two months $(29 \%)$. 34 of the public wanted the roadside trees to be maintained based on public complaints $(17 \%)$, and 12 of the public want it by every year (6\%). Properly maintenance will produce a healthy tree thus give the better environment to the human. Local authorities should have their maintenance programs and need to follow the programs schedule.

\subsection{Using Personal Protection Equipment (PPE) for maintenance workers}

Table 4 shows about using personal protection equipment (PPE) for maintenance workers. The majority of the public $(93.5 \%)$ agreed that workers using PPE to perform maintenance works while $(6.5 \%)$ disagreed on that. It can be concluded that we need more awareness among the public on safety. PPE is necessary to avoid the workers from gets an accident while doing the fertilizing, pruning and felling of trees (Nuranisyah, 2015). PPE will protect workers against health or safety risks at work. Local authorities should have protective equipment with safely designed and constructed and should be in a clean and reliable condition.

Table 4. Workers safety

\begin{tabular}{lll}
\hline PPE for workers & Respondents $(\mathrm{n})$ & Percentages $(\%)$ \\
\hline Yes & 187 & $93.5 \%$ \\
No & 13 & $6.5 \%$ \\
Total & 200 & $100 \%$ \\
\hline
\end{tabular}

(Source: Author)

\subsection{Conclusion}

Roadside tree management is a reduction of the hazard through inspection and mitigation, balancing the degree of hazard against the need to maintain large, beautiful trees on the site. 
This management is to enhance public safety makes the city more livable and improves the environment. Roadside planting with healthy condition properly care in urban areas have a direct impact on our community through the benefits they provide such as cooling the streets and the city, prevent soil erosion, block things and provide a canopy and habitat for wildlife. In this study has shown the important of the public preferences for roadside tree management in urban areas. It is a good effort to reduce the cost to maintain the tree which originally under the local authorities responsible. Furthermore, good management on roadside trees will reduce the public complaint on hazard trees. Thus, trees become healthier with properly maintenance. The selection of right tree species at the roadside is one of the factors that need to be considered for avoid the hazard occur. Public awareness of the risk of the roadside tree among the publics needs to improve as to create a better understanding of roadside tree management and improve the public safety. The safety management should be considered as a part of an integrated management plan that focuses on the wider management of the trees within a particular setting.

\section{Acknowledgement}

Authors gratefully acknowledge and grateful for the financial support of the Geran Inisiatif Penyelidikan (GIP) by Universiti Teknologi MARA for this research. Special thanks also to the reviewers for their invaluable comments on this paper.

\section{References}

Bureau of Construction, Tokyo Metropolitan Government. (2014). Tokyo Metropolitan street tree management regulations.

Chiu, H. Y. \& Chau, K. C. (2010). Best practices for urban tree management begin with sound institutional support and legislation. Department of Geography \& Resource Management, CUHK.

Hong Kong Conservancy Association. (2009). Urban tree management in Hong Kong problems and recommendations. pp 1-21.

Hisyam, K. (2014). Introduction to sustainable community based rural tourism.

Jabatan Landskap Negara. (2012). Piawaian produktiviti penyelenggaraan landskap edisi kedua.

John, J. (2012). Report of the committee on management of roadside trees.

Landscaping and Urban Cleaning Control Department. (2015). An opportunity for urban forest management.

Joan, T., Lorl, T., \& Paul, H. (2012). Hazard trees in Alaska. The identification and management of Hazard Tress in Alaska.

International Society of Arboriculture ISA. (2013). Basic tree risk assessment form.

Majlis Perbandaran Subang Jaya. (2015). Tree inventory report JKP Zone.MPSJ. 
Mohd, A. K., \& Noriah, O. (2011). Towards a better tomorrow: Street trees and their values in urban areas. Asia Pacific International Conference on Environment-Behaviour Studies.

Nuranisyah, (2015). Roadside tree management in Majlis Perbandaran Selayang.

Ruth, A., Rae, G. S., \& Jessie, B. (2010). Public reactions to new street tree planting. Article 10, 3(1).

Nor Azah, A. A. (2015). Ringkasan keperluan latihan pelanggan. institut latihan kesejahteraan bandar, perumahan dan kerajaan tempatan (IKPKT).

Ramzi, M. L. (2014). Tree risk management in Subang Jaya Zone. Unpublished Master of Urban Development and Management thesis.

Rafiuddin, R. (2011). Urban tree management: Towards best practices and application. case study: Kuala Lumpur. Unpublished Master of Science thesis.

Ronald, W. E., \& Hugh, W. M. (2008). Vegetation control for safety, a guide for local highway and street maintenance personnel.

Yaman, A. R., Jamil, M. Z., \& Yaakob, R. (2011). Manual pengurusan risiko pokok. 